\begin{tabular}{|l|l|l||}
\hline \multicolumn{2}{|c|}{ PublisherInfo } \\
\hline \hline PublisherName & $:$ & BioMed Central \\
\hline \hline PublisherLocation & $:$ & London \\
\hline \hline PublisherImprintName & $:$ & BioMed Central \\
\hline \hline
\end{tabular}

\title{
It only takes one bloom
}

\begin{tabular}{|l|l|l||}
\hline \multicolumn{2}{|c|}{ ArticleInfo } \\
\hline \hline ArticleID & $:$ & 4589 \\
\hline \hline ArticleDOI & $:$ & $10.1186 /$ gb-spotlight-20020924-01 \\
\hline \hline ArticleCitationID & $:$ & spotlight-20020924-01 \\
\hline \hline ArticleSequenceNumber & $:$ & 255 \\
\hline \hline ArticleCategory & $:$ & Research news \\
\hline \hline ArticleFirstPage & $:$ & 1 \\
\hline \hline ArticleLastPage & $:$ & 2 \\
\hline \hline & & RegistrationDate : 2002-9-24 \\
\hline ArticleHistory & $:$ & OnlineDate \\
\hline \hline ArticleCopyright & $:$ & BioMed Central Ltd2002-9-24 \\
\hline \hline ArticleGrants & $:$ & \\
\hline \hline ArticleContext & $:$ & 130593311 \\
\hline \hline
\end{tabular}




\section{Jonathan B Weitzman}

Email: jonathanweitzman@hotmail.com

Bloom syndrome (BS) is an autosomal recessive disorder in which mutation of the $B L M$ gene leads to cancer predisposition. In the September 20 Science two papers suggest that $B L M$ haploinsufficiency is sufficient for enhanced tumorigenesis. Goss et al. describe the generation of a mouse model for BS by creating a BlmCin mutation that mimics the mutated BLMAsh allele found in Ashkenazi Jewish patients (Science 2002, 297:2051-2053). Heterozygote $\mathrm{BlmCin} /+$ mice died earlier than controls following infection with murine leukemia virus and showed increased numbers of intestinal tumours when crossed with animals carrying the ApcMin mutation. The analysis by Goss et al. suggests that mutation of the wild-type $B l m$ allele was not required for tumour formation. These findings are supported by a report from Gruber et al. that $B L M$ heterozygosity may also lead to cancer predisposition in humans (Science 2002, 297:2013). They found that Ashkenazi Jews in New York who have colorectal cancer were twice as likely to carry the BLMAsh mutation as controls. The authors suggest that further analysis is required to determine whether haploinsufficiency or loss-of-heterozygosity is responsible for the tumorigenesis.

\section{References}

1. Bloom syndrome: a mendelian prototype of somatic mutational disease.

2. Science, [http://www.sciencemag.org] 